\title{
The Anaklysis of Factors that Affect Students Anxiety in Speaking for Presentation Class (A Study of the Fourth Semester Students at the English Education Study Program of University of Bengkulu in Academic Year 2018/2019)
}

\author{
Nadia Agustin \\ English Education Study Program, Department of Language and Art \\ University of Bengkulu \\ nadiaagustin97@gmail.com \\ Mulyadi \\ English Education Study Program, Department of Language and Art \\ University of Bengkulu \\ ladunimulyadi@gmail.com \\ Elfrida \\ English Education Study Program, Department of Language and Art \\ Universitas Bengkulu \\ mrs.elfrida@gmal.com
}

\begin{abstract}
This research attemted to find out the factors that affect students speaking anxiety in speaking for presentation class. This research was carried out by employing descriptive quantitative design. The population of this research was the fourth semester students of English Education Study Program of University of Bengkulu in academic year 2018/2019. The samples of this research were taken by using random sampling tehcnique, the total of the sample was 57 students. The data were collected by questionnaire consisted of 29 questions related to the anxiety. The results of this study showed that the students mostly had the mildly anxiety. There were three factors that causing the anxiety of the students in speaking; Fear of Negative Evaluation (Mildly Affected; Mean Score: 3.12), Communication Apprehension (Mildly Affected; Mean Score: 3.09), and Test Anxiety (Mildly Affected; Mean Score: 2.89). In conclusion, there were three factors that students speaking anxiety in speaking for presentation class and the most dominant factors is the Fear of Negative Evaluation.
\end{abstract}

Keywords: Anxiety, Factor, Presentation, Speaking, 


\begin{abstract}
ABSTRAK
Penelitian ini bermaksud untuk mengetahui faktor faktor yang menyebabkan kecemasan dalam kemampuan berbicara dikelas Speaking for Presentation. Penelitian ini dilakukan dengan menerapkan model penelitian deskriptif kuantitatif. Populasi dari penelitian ini adalah mahasiswa semester empat program studi pendidikan Bahasa Inggris di Universitas Bengkulu tahun ajaran 2018/2019. Sampel penelitian diambil dengan cara random sampling, yakni 57 mahasiswa. Data penelitian diambil dengan menggunakan kuisioner yang teridiri dari 29 pertanyaan yang berhubungan dengan kegelisahan yang diadaptasi dari questionnaire Horwitz et al (1986). Hasil dari penelitian menunjukkan bahwa hampir seluruh mahasiswa memiliki kegelisahan. Ada tiga faktor penyebab utama yang menyebabkan mahasiswa memiliki kecemasan berbicara di kelas presentasi ; Takut akan Evaluasi Negatif "Fear of Negative Evaluation" (Berpengaruh;Mean Score: 3.12), dan Ketakutan Berkomunikasi "Communication Apprehension" (Berpengaruh; Mean Score: 3.09). dan Kecemasan akan Test ( Test Anxiety) (Berpengaruh, Mean score : 2.89) Sebagai kesimpulan, bahwa ada tiga faktor utama yang menyebabkan kecemasan mahasiswa berkomunikasi dalam bahasa asing, dan faktor yang paling dominan adalah Ketakutan akan Evaluasi Negatif
\end{abstract}

Kata kunci: Berbicara, faktor, Kecemasan, presentasi

Introduction

Learning English is very important, because English has become an international language, which is used by most communities in the world. In learning English, Speaking skill is one of the four important language skills in the process of teaching and learning which is the basic function of language to communication. Speaking is the expression of contributing ideas, opinion, advice, their comments and interaction during teaching and learning process in the classroom. If the students want to be able to speak English the students should participate in the classroom. Because, if the students give the participation in the speaking class, automatically the students contribute their ideas. Currently, in University, English Department Students learn English as their major subject, but it is still categorized as a foreign language. Hence, even if they are the students of English Study Program, they are still rarely using English as their daily language to communicate with the others both in classroom and outside the classroom. Within the classroom itself, foreign language learning can be 


\section{Journal of English Education and Teaching \\ Volume 3 number 12019}

affected by anxious feelings especially when the learners do not achieve adequate proficiency in their speaking. There are so many factors that caused this kind of anxiety, as what has been divided by Horwitz, Horwitz\& Cope (1986). First, communication apprehension which arises from learners' inability, that they cannot adequately express mature thoughts and ideas. Second, fear of negative social evaluation, which arises from a learner's need to make a positive social impression on others. Third, test anxiety, an apprehension about academic evaluation.

Students' anxiety to speak English in front of audience is a problem commonly found in teaching speaking. Consequently, students can't improve their speaking ability. In learning speaking, Students speaking anxiety very important to be solved. The given research conducted on speaking anxiety revealed that students have extremely negative experiences with speaking activities in a foreign language class.

Based on preliminary observation in speaking class, the teacher usually used Bahasa Indonesia and English in teaching. When the teacher spoke in English, the students usually complain and ask the teacher to use Bahasa Indonesia in explaining something. This causes students to be unfamiliar with English. Many students experience a feeling of uneasiness and anxiety when having to speak in the foreign language especially to speaking english because a lack of preparation or, fear of the audience, fear of failure and fear that their speech is bad speech. As the researcher assume, this anxiety occurs among fourth semester students of English Education Study Program. Specifically, this anxiety mostly can be figured out in their speaking ability because speaking is ability that directly relate to the ability of the students in expressing their thought and ideas.

Based on phenomenon above the researcher are interested in conducting the research related to "The Analysis of Factor's that Affect Students Speaking Anxiety in Speaking for Presentation Class (a Study at the Fourth Semester Students of English Education Study Program of UNIB in Academic Year 2018/2019). 


\section{Method}

This study used descriptive quantitative method to answer the research. According to Arikunto (2010), quantitative research is an attempt to investigate an issue by using numerical data and statistical processing. Descriptive method is to find the answer of questions and to test hypothesis concerning the current situation of the subject of the research when there is certain phenomenon or situation happened.

The subject of this research was students of fourth semester at English Study Program in University of Bengkulu in Academic Year 2018/2019. The total is 3 classes: class A,B and C. There are 103 students. The researcher chooses the research subject, because based on the researcher experience semester fourth have a quite longer experience in learning English. The research subject of this study were 57 students. The instruments of this research were questionnaire and interview. First is questionnaire which used to measure the level of anxiety as well as the possible factors that are affected the anxiety.

The instrument used in this study was adapted from Foreign Language Classroom Anxiety Scale (FLCAS) proposed by Horwitz et al. (1983). FLCAS have 33 items but in order to make it more relatable to the background of the students of English Department in University of Bengkulu, the researcher make several changes helped by the expert who are done the validation of the questionnaire. Then, interview After the questionnaire was given to the students and their level of anxiety has been measured as the students with middle to high anxiety level. Several students was taken as the respondent to be interviewed in order to confirm what the major causes that make them feeling anxious. 


\section{Result and Discussion}

\section{Result}

The data of this research has been collected in February $5^{\text {th }} 2019$. The questionnaire distributed after 'Speaking for Presentation' class. The total number of student that answers the questionnaire was 57 students. The data of this research has been analyzed to get the mean and percentage level of the students' anxiety and the factors causing it.

\section{Table 1 : Factors that Affect Students' Anxiety in Speaking for Presentation}

\begin{tabular}{|c|c|c|}
\hline No & Speaking Anxiety Group & $\begin{array}{c}\text { Mean } \\
\text { Scores }\end{array}$ \\
\hline 1 & Fear of Negative Evaluation & 3.12 \\
\hline 2 & Communication Apprehension & 3.09 \\
\hline 3 & Test Anxiety & 2.89 \\
\hline
\end{tabular}

As the table above, it could be concluded that the most factors that affect student speaking anxiety was the Fear of Negative Evaluation with mean score 3.12. It means the sources of the student speaking anxiety in speaking for presentation class mostly came from the Fear of Negative Evaluation. It was also supported from the interview data, Some of them confirmed if they did not confident because they might commit a mistake in speaking so their friend will laugh at them and they were afraid of the attention that all directed to them.

Table 2 : The Result of Students' Anxiety Level

\begin{tabular}{|c|c|c|}
\hline Number of Students & Percentage & Category/Predicate \\
\hline 1 & 1.75 & Very Anxious \\
\hline 3 & 5.26 & Anxious \\
\hline 50 & 87.71 & Mildly Anxious \\
\hline 3 & 5.26 & Relaxed \\
\hline 0 & 0.00 & Very Relaxed \\
\hline
\end{tabular}

From the represented data in table 3 , the result were as follows, 1 student (1.75\%) was indicated in "Very Anxious" level, 3 students (5.26\%) were indicated in "Anxious" level, 50students (87.71\%) were indicated in "Mildly Anxious" level. 3 students (5.26\%) were indicated in "Relaxed" level, and 0 students (0.00 \%) were indicated in "Very Relaxed" level. The 
data indicate that the majority of the students (50 out of 57 ) were in the level of Mildly Anxious.

\section{Discussion}

This research tried to know the factors that frequently experienced by the students when they spoke English in the Presentation class. According to Horwitz et al (1986) which are Test Anxiety, Communication Apprehension and Fear of Negative Evaluation. The researcher found from the three categories, the Fear of Negative Evaluation was the dominant factor causing the anxiety. This happened because they were afraid of making mistake. It was known that the majority of the students (50 out of 57) fall into mildly anxious level, which indicated that the overall level of anxiety of the Fourth Semester students is Mildly Anxious.

Table 3. Factors that Affect Students Speaking Anxiety :

\begin{tabular}{|c|c|c|}
\hline No & Speaking Anxiety Group & Mean Scores \\
\hline 1 & Fear of Negative Evaluation & 3.12 \\
\hline 2 & Communication Apprehension & 3.09 \\
\hline 3 & Test Anxiety & 2.89 \\
\hline
\end{tabular}

From the table above, the most factors that affect student speaking anxiety was the Fear of Negative Evaluation. It means the sources of the student speaking anxiety in speaking for presentation class mostly came from the Fear of Negative Evaluation.

From the item number in Fear of Negative Evaluation, The highest average was the item number 7; I think that the other students are better that I am in English presentation. It became the most factor that affect students' anxiety related to fear of negative evaluation, it revealed that this factor also takes part in causing students anxiety. The interview data also confirmed that mostly respondents are afraid if they were speaking in front of their friends. For example, respondent 1 stated. " in a group all the attention of my friends is directed to me, this makes me so nervous to speak". 
This statement supported by Lamhot (2018) he studied about the factors of anxiety of the seventh semester students of English Study Program in language Teaching Seminar class. He stated that Fear of Negative Evaluation was the main factor. Based on the result of the FLCAS, it was evident that students were already anxious because they were afraid of making mistake while their speaking and being evaluated by the lecturer and their friends. The reasons were because they worried in committing mistake when they speak in front of their friends.

The lowest average was questionnaire item number 27, I feel okay speaking in front of the class, even when I know the other students will laugh at me when I am speaking in presentation. The questionnaire of fear of negative evaluation conducted by researchers, students feel anxious and not confident when they talk in front of friends in the presentation class especially when they friends will laugh.

The second highest weighted mean was Communication Apprehension. The highest average was the item number 9; I start to panic when I have to speak without preparation in Speaking for presentation class. The first item in Communication Apprehension term strongly affected students' anxiety in speaking this had supported by the result of interview from respondent 3 . She said that she got anxious and can't think about something if the lecturer asked her to speak without preparation.

This communication apprehension also supported by Sutarsyah (2017) It can be concluded that this term also took part in causing the students anxiety. Because several respondent answered they were afraid of speaking because they were rarely by using English, they also scared when he was asked to speak in front of class without preparation. The lowest average was questionnaire item number 28 , I would probably feel motivated to speak when I am around native speakers of English.

The lowest weighted mean was Test Anxiety. It became the third factor that affect students anxiety in speaking for presentation class. The highest average was the item number $10 ;$ worry about the consequences of failing my speaking for presentation class. 
This statement also supported by Mayangta (2013) but she found that the most dominant factors that causing anxiety among the students was the Test Anxiety. She stated that the students worried if they could not create appropriate sentences, they forgot the things that they know or just go blank when they had prepared all the material. The lowest average was the item number 21 , I dont afraid of making mistake in speaking for presentation class, the mean score was indicated that, this item less affected factors that causing student's anxiety in speaking.

Based on the discussion above, the researcher concluded that most of the fourth semester students of English Study Program were mildly anxious. There are several factors that affect students speaking anxiety in speaking for presentation class and mostly factors were caused by Fear of Negative Evaluation.

Concerning this factor above, in fact, they have a feeling of anxious because they were rarely speak by using English. And they would feel anxious whenever they were asked to speak because they felt that they were unprepared and that they were not confident with their English proficiency. The researcher believes that those negative suggestions would worsen the anxious feeling of the students.

This research only revealed the external factors of the students' anxiety in speaking. The data were gathered by using questionnaire. The results of the questionnaire might be inconsistent because it depends on the subject being analyzed. The subject sometime can make up their mind while answering the questionnaire, so that the result of the questionnaire tends to be bias. This research only reveals the external factors that caused foreign language anxiety in speaking. Hopefully, the further research will analyze it much deeper into the internal factors and the way how to cope with the anxiety. 


\section{Conclusion and Suggestion}

\section{Conclusion}

After doing the research and investigate the factors that affect students' speaking anxiety in speaking for presentation class at the fourth semester students of English Study Program, the researcher draw a conclusion based on the research question. There were several factors that affect students speaking anxiety in speaking for presentation class ,experienced by the fourth semester students of English Study Program in academic year 2018/2019.

First, Fear of Negative Evaluation with weighted average of 3.12 (Mildly Affected). Second, Communication Apprehension with weighted average of 3.09 (Mildly Affected). Third, Test Anxiety with weighted average of 2.89 (Mildly Affected).

The most dominant factor that affect students speaking anxiety in speaking for presentation class was Fear of Negative Evaluation with mean score of 3.12. Fear of negative evaluation is a psychological construct reflecting "apprehension about others' evaluations, distress over negative evaluations by others, and the expectation that others would evaluate one negatively". People who score high on the Fear of negative evaluation scale are highly concerned with seeking social approval or avoiding disapproval by others, and may tend to avoid situations where they have to undergo evaluations. High fear of negative evaluation subjects are also more responsive to situational factors. Based on the conclusion of this research, suggestions are given as the following .

First for the lecturer. Basically, the lecturer should aware if most of their students were anxious; therefore the lecturers should make a comfortable situation in teaching and learning to increase the quality of teaching and learning activities.

Second, For Further Research, the researcher suggests that there should be a test speaking in the next research. in order to make the research becomes clearer and more detail to see the factors and symptom that causing the foreign language anxiety in speaking. The next research is 
also need to be more focus on the best method to reduce the anxiety that felt by the students.

Third, For students. This study suggested some recommended ways based on the finding and interview to reduce the possibility of anxiety in speaking. The students need to understand if anxiety is a normal feeling that experienced by everyone. They should realize if they can control that feeling by controling their mind. So at the end they will be able to prepare themselves well.in order make students have a better preparation in presentation before they speak in front of the class.

\section{References}

Arikunto,S.2008. Prosedur Penelitian: Suatu pendekatan praktek. Jakarta: Rineka Cipta.

Arikunto,S.2010. Prosedur Penelitian: Suatu pendekatan praktek. Jakarta: Rineka Cipta.

Horwitz, E. K.1983. Language anxiety and achievement. Annual Rev. Appl. Linguistics, 21:112-126.

Horwitz, Horwitz\& Cope.1986. Foreign Language Anxiety, The Modern Language Journal, Vol. 70, 1986, p. 127.

Horwitz, E. K., Horwitz, M. B., \& Cope, J. 1986. Foreign language classroom anxiety.The Modern Language Journal, 70, 125-132

Lamhot, A. 2018. A Study of Students' Anxiety in Language Teaching Seminar Class at the Sixth Semester Students of English Education Study Program of University of Bengkulu in Academic Year 2018/2019.Universitas Bengkulu: Unpublished Thesis

Mayangta, T. 2013. Students' Speaking Anxiety in an EFL Classroom. Bandung: Unpublished Thesis.

Sutarsyah.2017. Investigated students' speaking anxiety and its effect on speaking performance. Lampung: Unpublished Thesis. 
Writer Information

\begin{tabular}{|l|l|}
\hline Name & Nadia Agustin \\
\hline Affiliation & $\begin{array}{l}\text { English Education Study Program, Department of } \\
\text { Language and Art, University of Bengkulu }\end{array}$ \\
\hline Email & nadiaagustin97@gmail.com \\
\hline Phone Number & 082178114045 \\
\hline
\end{tabular}


Journal of English Education and Teaching

Volume 3 number 12019 